Revue Française de Civilisation Britannique

\title{
Review of In Search of the Perfect Health System by Mark Britnell
}

\section{Hira Rashid}

\section{(2) OpenEdition}

\section{Journals}

\section{Electronic version}

URL: http://journals.openedition.org/rfcb/4174

DOI: $10.4000 /$ rfcb.4174

ISSN: 2429-4373

\section{Publisher}

CRECIB - Centre de recherche et d'études en civilisation britannique

\section{Electronic reference}

Hira Rashid, «Review of In Search of the Perfect Health System by Mark Britnell », Revue Française de Civilisation Britannique [Online], XXIV-3 | 2019, Online since 30 August 2019, connection on 04 September 2019. URL : http://journals.openedition.org/rfcb/4174 ; DOI : 10.4000/rfcb.4174

This text was automatically generated on 4 September 2019

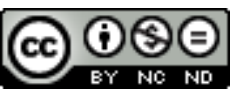

Revue française de civilisation britannique est mis à disposition selon les termes de la licence Creative Commons Attribution - Pas d'Utilisation Commerciale - Pas de Modification 4.0 International. 


\title{
Review of In Search of the Perfect Health System by Mark Britnell
}

\author{
Hira Rashid
}

\section{REFERENCES}

Mark Britnell, In Search of the Perfect Health System, Palgrave and Macmillan, 2005, 233

p. ISBN 978- 1- 137- 49661- 4

1 In Search of the Perfect Health System captures the workings of incredibly diverse health systems in 25 chapters that provide brief but relevant country contexts, ranging from the formation and evolution of sickness funds in Germany in the 1883 and health management organizations in Israel in 1995, to the recent push for Kaigo Hoken ${ }^{1}$ in Japan at the turn of the $21^{\text {st }}$ century. This book aptly captures the similarities across health systems such as limited public financing and coverage gaps between countries with sharp cultural and political contrasts -the United States and China, for example. It documents the economic and political forces spurring the wave of privatization in the welfareoriented economies of the Nordic countries and tracks the intersection of healthcare innovation and public health policies in the rapidly growing countries of Mexico, Brazil and India.

2 However, it would be overly simplistic to view this work as a series of descriptive essays that summarize the workings of the health systems of countries around the world. Instead it is more accurately described as a commentary on the political, ideological, economic and cultural forces that shape the national and regional health systems of the world, and the strategies used by policy actors to tackle the challenges that arise.

3 This review first discusses five prominent themes that Britnell highlights through the course of the book, with notable examples from his analyses of national health systems. It then moves on to a critical analysis of the structure and content knowledge, and finally concludes with a brief section on lessons learnt and implications of this work. 

of numerous strategies and practices worth replication within selected health systems he discusses in the book. In addition to a description of the financial distribution of healthcare costs, notable health indicators, healthcare delivery mechanisms, consumer access and patient satisfaction measures, each chapter provides critical insights into key policy measures undertaken by local or national policy actors to improve outcomes, reduce costs, or both.

5 The most valuable aspect of this analytical exercise, obviously attributable to Britnell's extensive experience in the global healthcare industry, is the linkage of policy development to its eventual impact, and the lessons to be learnt from this process. For example, despite Portugal's progress, Britnell traces the beginnings of a declining health infrastructure, higher out-of-pocket costs, reduced compensation for the healthcare workforce and a general disinvestment from the healthcare sector. He attributes this to the economic collapse, austerity measures and declining living standards in the country. Qatar, on the other hand, driven by the ambition to make its mark on the world, and unencumbered by resource constraints, launched an expensive National Health Strategy in 2011 and has even taken steps towards the launch of a universal health insurance system. However, as Britnell points out, the prioritization of channeling resources towards the construction of new hospitals may not necessarily lead to proportional improvements in population health.

Second, the book does a commendable job of delineating the drivers of fragmentation in the healthcare system as well as how it manifests through underutilization of available capacity, coverage gaps, depreciating quality of care, waste in the healthcare industry, overly burdensome administrative tasks for doctors and, subsequent declines in patient satisfaction rates and health outcomes. A consistent critique he levies on health systems developed and developing - is the lack of standardized regulatory and quality control measures integrated and enforced by a central governance system at the country level.

This fragmentation, Britnell points out, is creating an increasing demand for private health insurance among consumers who are able to afford it, thereby reinforcing existing health inequities. The intersection of health policy and access barriers to essential health services grounded in socioeconomic, geographic and demographic inequities is woven into Britnell's analysis. In the concluding chapters of the book, he aptly notes "two forces - globalisation and wealth inequality - will create fertile ground for the development of universal healthcare but its successful introduction cannot be taken for granted" (p. 155).

Third, true to his claim in the introductory comments, Britnell engages practitioners, policy makers and politicians by connecting the dots between hot button political issues and often understated, but vital aspects of the healthcare industry. He captures the impact of workforce shortages in countries like Japan, Hong Kong, Mexico, India and Brazil, where healthcare access is a growing priority for the electorate. He discusses the long-lasting impact of workforce immigration policies as ambitious, well-resourced countries like Qatar draw skilled professionals from the Global North and highlights potential issues with sustainability in the absence of local workforce education and training programs. He draws attention to the increasingly globalized nature of healthcare consumption by presenting examples of the increasing rates of medical tourism in South Korea, Malaysia, Singapore and Mexico.

Revue Française de Civilisation Britannique, XXIV-3 | 2019 
9 Fourth, a consistent unifying theme in Britnell's analysis of these systems and policy measures is the importance of dynamism - policy action and institutional reorganization to address the evolving patterns of communicable diseases, chronic illnesses and ageing. He draws on the example of Brazil, where near-universal access to primary care and workforce distribution strategies to promote family-centered care models has contributed to considerable improvements in health outcomes. Singapore and Japan have introduced new insurance schemes with varying degrees of consumer choice to address the needs of its growing elderly population. South Africa is striving to contain the burden of communicable diseases by expanding access to screening and preventive interventions to remote rural areas using Tutu Tester mobile clinics, while Germany amidst growing pressures to contain growing healthcare costs, has taken steps to improve integration of care and taken legal measures to protect patient rights.

10 Finally, Britnell strongly advocates for patient empowerment in healthcare, urging healthcare delivery systems in developed countries to learn from the initiative of African nations such as Uganda and South Africa. He argues that despite the capital-intensive technological advancement and efficiency enhancing measures in banking and retail industries in countries like Germany, France and Switzerland, healthcare has lagged behind in terms of emotional and social support for patients, particularly those suffering from chronic conditions. He attributes this to two factors: "empowering patients has been viewed as the 'right thing to do' rather than crucial to the economic sustainability of healthcare systems, so it has not been pursued with any urgency; and clinicians are wary of the idea because it changes the power relationship between them and their patients" (p. 187).

11 Brevity is perhaps the most attractive feature of this book, yet its most significant limitation. Without further research into each country, one runs the risk of being illinformed on the workings of these health systems, and the populations they serve. However, in his defense, Britnell opens with the claim that "each chapter can be read in the time it takes to drink a cup of coffee. This is not an academic treatise..." (preface). The book is unquestionably informative, but readers must understand its purpose to be that of an introductory discourse, since it embodies Britnell's own perspective thus presenting only selective information about the complexity of how they function.

12 An important underexplored theme in this book is the intersection of investments in public health with the performance of the health systems. Recognizing the importance of this aspect of any health system, Britnell notes "we wouldn't start from where we are, knowing what we now know" (p.211). Despite this, the country level analysis does not do justice to the significance of this statement. While he highlights the high immunization rates and tobacco control policies in Brazil, screening and lifestyle programs in Mexico and the concentration of socioeconomic risk factors among the aboriginal population of Australia, there is little that speaks to the integration of public health policy into the way health systems around the world are structured.

13 The improvement of health outcomes through the creation of accessible health services has increasingly been recognized as an instrumental aspect of the political and economic trajectory of a country. On the one hand, country governments face internal pressures induced by comparative insights into the drivers of affluence and longevity of the populations of the developed world. While on the other, rapidly shifting demographics, stagnating economies and growing gaps in quality of care have given rise to political unrest and unpopular financial restructuring to bring costs down. Consequently, health 
systems around the world are struggling to adapt to the changing needs of the populations they are designed to serve, which also straddling the line between cost efficiency and expected quality standards. Despite its title, the book does not in fact identify a 'perfect' health system, it does give the reader a realistic perspective of the issues facing those that are considered to be some of the best and is a timely contribution to the debate many economies around the world are facing.

\section{NOTES}

1. Kaigo Hoken refers to the long-term care scheme in Japan, which is expected to improve quality of life for the elderly population.

\section{AUTHOR}

\section{HIRA RASHID}

Research Assistant, Center for Community Research and Service, School of Public Policy and Administration, University of Delaware 